\title{
Silica-scaled chrysophytes from Abisko (Swedish Lapland)
}

\author{
Martina Pichrtová, Kateřina Janatková and Yvonne Němcová \\ M. Pichrtová (pichrtov@natur.cuni.cz), K. Janatková and Y. Němcová, Dept of Botany, Faculty of Science, Charles Univ. in Prague, Benátska' \\ 2, CZ-128 01 Praha 2, Czech Republic.
}

\begin{abstract}
The silica-scaled chrysophyte flora of Swedish Lapland (near Abisko) was examined. Chrysophyte scales were found in 18 of the 32 investigated water bodies (lakes and pools). Altogether, 28 taxa from the classes Chrysophyceae and Synurophyceae were found. The most abundant species was Synura echinulata. Three species were observed for the first time in Sweden: Mallomonas maculata, M. rasilis and Spiniferomonas serrata.
\end{abstract}

The term 'silica-scaled chrysophytes' refers to the members of algal classes Chrysophyceae and Synurophyceae, whose cells are covered with a layer of silica structures (scales, spines or bristles). The species determination within both classes is traditionally based on the morphology of those structures. Moreover, the total number of described species is relatively low (around 300) in comparison to other algal groups. The scales can remain intact in lake sediments for long periods of time, which make chrysophytes ideal for various ecological, paleoecological and biogeographical studies.

Based on geographic distribution, chrysophytes have been divided into several groups or distribution types (Kristiansen 2001, 2008). Alternatively, the likelihood of ubiquitous distribution of chrysophytes has also been proposed and discussed (Finlay and Clarke 1999, Řezáčová and Neustupa 2007). In addition, a number of species are still regarded as regional endemics (Kristiansen and Lind 2005). However, the observed restricted distributions and the endemism might be, in some cases, a result of insufficient sampling. In fact, there are studies that report surprising findings for species previously believed to have very restricted distribution (Janatková and Němcová 2009, Němcová and Pichrtová 2009). Furthermore, repeated sampling in the same region usually brings slightly different results with new records of some chrysophyte species (Pichrtová and Veselá 2009).

Consequently, in chrysophyte research it is essential that we conduct floristic surveys of different regions. These surveys, accompanied by data for environmental variables, not only provide new information concerning national chrysophyte floras, but can provide evidence to test hypotheses concerning ecology and biogeographical patterns.

There is a distinct group of chrysophytes with bipolar distribution, but also those that have, thus far, only been found in the Northern Hemisphere (Kristiansen 2001). However, it seems that there is no typical Arctic chrysophyte flora; the most common species in the Arctic regions are generally cosmopolitan and widespread (Kristiansen 2001, Siver et al. 2005).

The silica-scaled chrysophytes of Swedish Lapland have been investigated previously, but there are only few studies. Initially, Petersen and Hansen (1958) reported members of the genus Synura from material provided by Skuja. Recently, one study was published that focused on small acidic water bodies in bogs and fens (Němcová et al. 2008). In the current research, our goal was to expand this study to include a wide range of localities, both lakes and small pools, in a more extensive area surrounding Abisko.

\section{Material and methods}

Our investigation included 32 water bodies in the region surrounding Abisko (about $68^{\circ} \mathrm{N}$ ) and was conducted in August 2008. A map of the research area is shown in Fig. 1. Sampling sites were divided among 5 different regions. Sampling region (A) included water bodies closest to Abisko, (B) was confined to the area surrounding lake Vassijaure, (C) comprised several pools at Kårsavagge, (D) represented mountain pools on the ridge of Njulla, and (E) included lakes and pools situated near the main road towards Kiruna. We also collected samples from lake Torneträsk, but we did not find any chrysophyte scales there.

At each sampling site we collected plankton using a plankton net (mesh size $20 \mu \mathrm{m}$ ). In addition, we also sampled the sediment layer in order to encompass the entire seasonal variability of silica-scaled chrysophytes, and not simply those living cells present in the water column. Samples of the upper layer of sediment were taken by a $20 \mathrm{ml}$ syringe. We measured temperature, $\mathrm{pH}$ and conductivity using a portable meter (WTW pH/Cond 


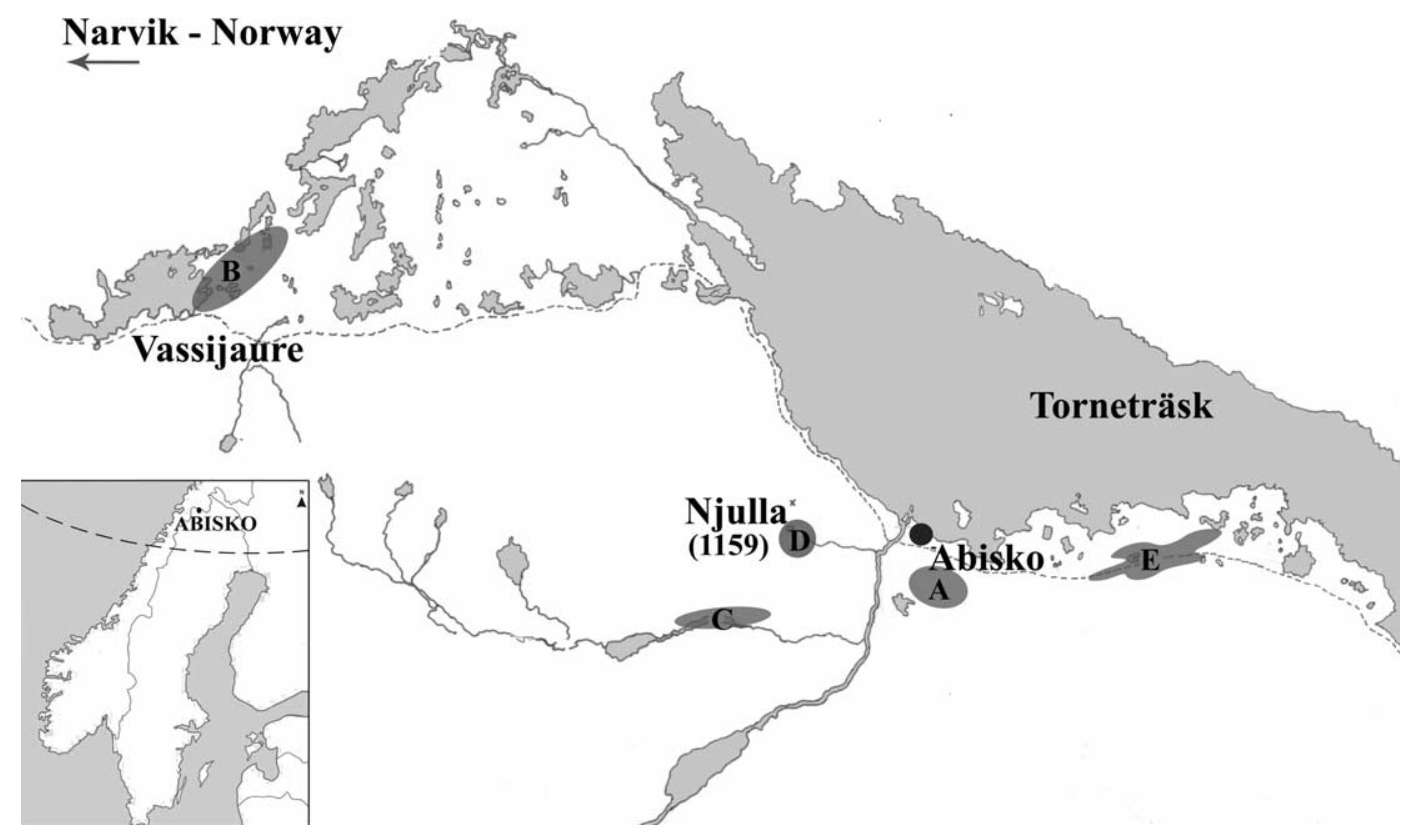

Figure 1. A map of the investigated area divided into 5 sampling regions (A)-(E). Region (A) includes sampling site 1, (B) comprises sites 2-8, (C) includes 9, (D) comprises 10 and 11, and (E) sites 12-18. The Arctic Circle is indicated.

340i). The map coordinates were determined with GPS equipment (Global Positioning System).

After returning to the laboratory, the plankton samples were briefly examined under light microscopy. All samples were then fixed with Lugol's solution, later dried on formvar-coated copper grids and washed in a series of water droplets. The grids were then examined in a TEM JEOL 1011 electron microscope.

\section{Results and discussion}

In total, 18 of the 32 sampled water bodies contained chrysophyte scales and at times also living cells were observed under the light microscope. The main characteristics of those
18 sites are summarized in Table 1 . The distribution of recorded chrysophyte species within the localities is shown in Table 2. Investigated water bodies were oligotrophic, rather pristine lakes or pools, and quite similar in their values for the measured parameters. The average $\mathrm{pH}$ of the sites was 6.43 and it ranged between 6 and 7 in most cases. Interestingly, the environmental parameters did not differ in the sites where no chrysophyte scales were found. All water bodies were also quite low in specific conductivity. Although we attempted to sample diverse sites, including typical bog pools with Sphagnum, we were unable to find any markedly acidic localities, such as those reported by Němcová et al. (2008).

Despite their similarity in water $\mathrm{pH}$ and conductivity, the investigated sites were very different in their chrysophyte flora, in terms of both abundance and diversity. Locality

Table 1. List of sampling sites where chrysophyte scales were recorded. The main environmental characteristics and location of the sites are provided.

\begin{tabular}{llcccc}
\hline Sampling site & $\mathrm{pH}$ & Conductivity $\left(\mu \mathrm{S} \mathrm{cm}{ }^{-1}\right)$ & Temperature $\left({ }^{\circ} \mathrm{C}\right)$ & Latitude $(\mathrm{N})$ & Longitude $(\mathrm{E})$ \\
\hline 1 & 7.8 & 125 & 12.1 & $68^{\circ} 20.549^{\prime}$ & $18^{\circ} 46.550^{\prime}$ \\
2 & 6.5 & 73 & 12.0 & $68^{\circ} 25.780^{\prime}$ & $18^{\circ} 15.435^{\prime}$ \\
3 & 6.5 & 32 & 11.4 & $68^{\circ} 26.395^{\prime}$ & $18^{\circ} 15.989^{\prime}$ \\
4 & 6 & 21 & 11.0 & $68^{\circ} 26.495^{\prime}$ & $18^{\circ} 15.979^{\prime}$ \\
5 & 6.2 & 50 & 12.3 & $68^{\circ} 26.638^{\prime}$ & $18^{\circ} 15.218^{\prime}$ \\
6 & 6.3 & 16 & 12.0 & $68^{\circ} 26.038^{\prime}$ & $18^{\circ} 15.572^{\prime}$ \\
7 & 6.5 & 26 & 11.8 & $68^{\circ} 26.501^{\prime}$ & $18^{\circ} 16.830^{\prime}$ \\
8 & 6.5 & 31 & 11.9 & $66^{\circ} 27.117^{\prime}$ & $18^{\circ} 16.800^{\prime}$ \\
9 & 5.6 & 42 & 11.0 & $68^{\circ} 20.297^{\prime}$ & $18^{\circ} 39.056^{\prime}$ \\
10 & 6.3 & 50 & 10.8 & $68^{\circ} 21.889^{\prime}$ & $18^{\circ} 41.667^{\prime}$ \\
11 & 6.3 & 80 & 9.0 & $68^{\circ} 21.849^{\prime}$ & $18^{\circ} 42.128^{\prime}$ \\
12 & 6.3 & 61 & 9.0 & $68^{\circ} 20.950^{\prime}$ & $18^{\circ} 58.174^{\prime}$ \\
13 & 6.5 & 77 & 10.0 & $68^{\circ} 20.928^{\prime}$ & $18^{\circ} 50.069^{\prime}$ \\
14 & 6.5 & 66 & 10.3 & $68^{\circ} 20.966^{\prime}$ & $19^{\circ} 01.409^{\prime}$ \\
16 & 6.7 & 77 & 10.6 & $68^{\circ} 20.894^{\prime}$ & $19^{\circ} 02.355^{\prime}$ \\
17 & 6.4 & 74 & 11.0 & $68^{\circ} 20.946^{\prime}$ & $19^{\circ} 04.400^{\prime}$ \\
18 & 6.5 & 38 & 10.3 & $68^{\circ} 20.948^{\prime}$ & $19^{\circ} 04.729^{\prime}$ \\
\hline
\end{tabular}


Table 2. List of species and their distribution within investigated localities. $\mathrm{X}=$ species present, $\mathrm{X}-\mathrm{S}=$ species found exclusively in sediment samples.

\begin{tabular}{|c|c|c|c|c|c|c|c|c|c|c|c|c|c|c|c|c|c|c|}
\hline \multirow[t]{2}{*}{ Species } & \multicolumn{18}{|c|}{ Sampling site number } \\
\hline & 1 & 2 & 3 & 4 & 5 & 6 & 7 & 8 & 9 & 10 & 11 & 12 & 13 & 14 & 15 & 16 & 17 & 18 \\
\hline Chrysosphaerella brevispina Korshikov & & & & $x$ & & & & & & & & & $x$ & $x$ & $x$ & & & $X-S$ \\
\hline Chrysosphaerella longispina Lauterborn & & & & & & & & & $\mathrm{X}-\mathrm{S}$ & & & & $\mathrm{X}$ & & & $X-S$ & $x$ & \\
\hline Mallomonas cf. acaroides Perty em. Ivanov & & & & & $X$ & & & & & & & & $x$ & $x$ & $x$ & & $x$ & \\
\hline Mallomonas akrokomos Ruttner in Pascher & & $x$ & $X-S$ & & & & & $X-S$ & $x$ & & & & & & $x$ & & & \\
\hline Mallomonas alata f. alata Asmund et al. & & & & & & & & & & & & & $X-S$ & & & & & \\
\hline $\begin{array}{l}\text { Mallomonas alpina Pascher \& Ruttner in Pascher emend. Asmund \& } \\
\text { Kristiansen }\end{array}$ & & $x$ & $X-S$ & & & & & & & & & & & & $x$ & & & \\
\hline Mallomonas caudata Ivanov em. Krieger & $x$ & & & & & & & & & & & & & & & & & $x$ \\
\hline Mallomonas crassisquama (Asmund) Fott & & $\mathrm{x}$ & $\mathrm{x}$ & $x$ & & $\mathrm{x}$ & & $x$ & & & & $\mathrm{x}$ & $x$ & & & & & $x$ \\
\hline Mallomonas heterospina Lund & & & & & & & & & & & & & $x$ & & & & & \\
\hline Mallomonas insignis Penard & & & & & & & & & & & & & $x$ & & & & & \\
\hline Mallomonas maculata Bradley & & & & & & & & & & & & & & & & $X-S$ & & \\
\hline $\begin{array}{l}\text { Mallomonas matvienkoae var. matvienkoae (Matvienko) Asmund \& } \\
\text { Kristiansen }\end{array}$ & & & & & & & & & $\mathrm{X}-\mathrm{S}$ & & & & $\mathrm{X}$ & & & & & \\
\hline Mallomonas papillosa var. papillosa Harris \& Bradley em. Harris & & & X-S & $\mathrm{x}$ & & & & & $x$ & & & & $x$ & & & & $x$ & $x$ \\
\hline Mallomonas pillula f. valdiviana Dürrschmidt & & & & & & & & & & & & & $\mathrm{X}$ & & & & & $\mathrm{X}-\mathrm{S}$ \\
\hline Mallomonas rasilis Dürrschmidt & & & & & & & & & & & & & $\mathrm{X}-\mathrm{S}$ & & & & & \\
\hline Mallomonas striata Asmund & $x$ & & & & & & & & & $\mathrm{X}-\mathrm{S}$ & & & $\mathrm{x}$ & & & $x$ & & \\
\hline Mallomonas tonsurata Teiling em. Krieger & $\mathrm{X}$ & & & & & & & & & & & & & & & & & \\
\hline Mallomonas sp. & & & & & & & & & & & & & $\mathrm{X}$ & & & & & \\
\hline Paraphysomonas imperforata Lucas & & & X-S & & & & & & & & & & & & & & & \\
\hline Paraphysomonas vestita (Stokes) De Saedeleer & & & X-S & & $\mathrm{x}$ & & & & & & & & $\mathrm{X}$ & $X-S$ & & $\mathrm{X}-\mathrm{S}$ & $X-S$ & \\
\hline Spiniferomonas bourrellyi Takahashi & & & & & & $\mathrm{x}$ & & & & & & & & & & & & \\
\hline Spiniferomonas serrata Nicholls & & $\mathrm{X}$ & $\mathrm{x}$ & & & & & $x$ & & & & & & & & & & \\
\hline Spiniferomonas trioralis Takahashi & $x$ & & & & $x$ & & & & & & & & & & & & & \\
\hline $\begin{array}{l}\text { Synura echinulata Korshikov } \\
\text { Synura lapponica Skuja }\end{array}$ & & & $\mathrm{X}-\mathrm{S}$ & $\mathrm{X}$ & $x$ & $X-S$ & $\mathrm{X}$ & $\mathrm{X}-\mathrm{S}$ & $\mathrm{X}-\mathrm{S}$ & & $\mathrm{X}-\mathrm{S}$ & $x$ & $\mathrm{X}$ & $x$ & $x$ & $\mathrm{X}-\mathrm{S}$ & $X-S$ & $x$ \\
\hline $\begin{array}{l}\text { Synura lapponica Skuja } \\
\text { Synura petersenii Korshikov }\end{array}$ & & & $x$ & & & $\mathrm{X}-\mathrm{S}$ & & X-S & $X-S$ & & & & $\mathrm{x}$ & $x$ & $\lambda$ & $X$ & $\begin{array}{l}\lambda-5 \\
X-S\end{array}$ & \\
\hline Synura sphagnicola (Korshikov) Korshikov & & & & $\mathrm{x}$ & & $X-S$ & $\mathrm{X}-\mathrm{S}$ & & & & & & $x$ & & & $X-S$ & $\mathrm{X}-\mathrm{S}$ & $x$ \\
\hline Synura uvella Ehrenberg em. Korshikov & & & & & & & & & & & & & $x$ & & $x$ & & & \\
\hline
\end{tabular}



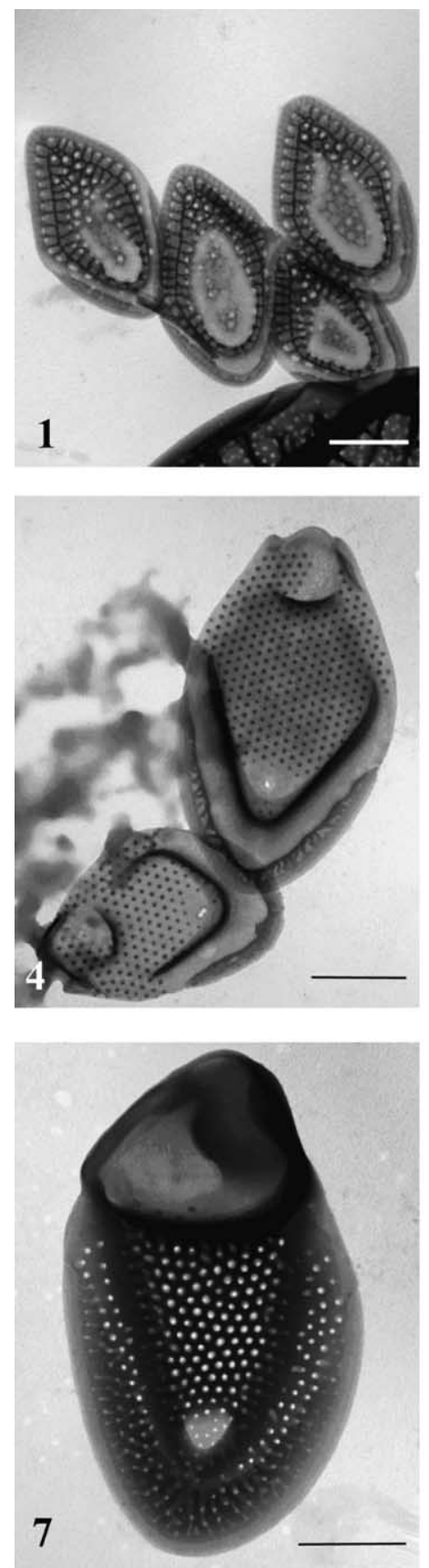
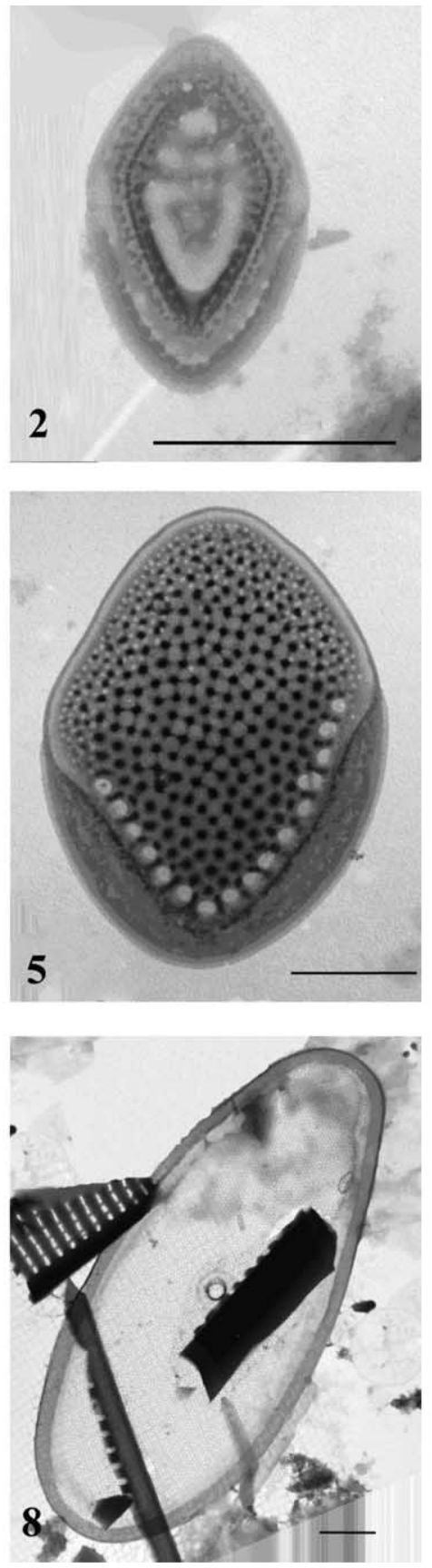
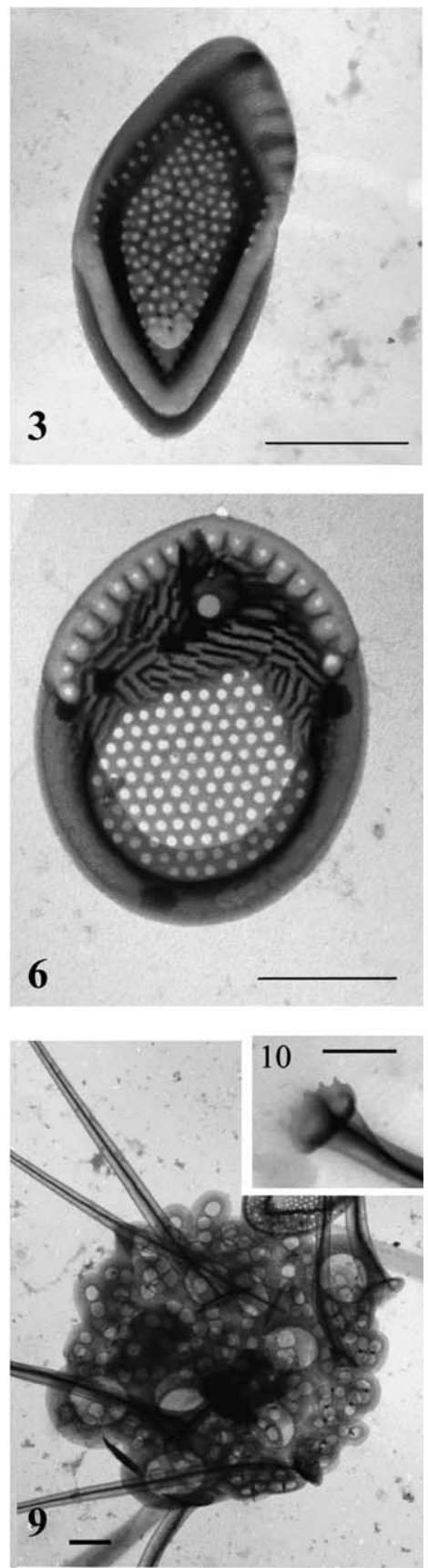

Figure 2. Silica scales of some chrysophyte species found in Abisko. $1=$ Mallomonas sp., $2=$ M. pillula f. valdiviana, $3=$ M. alata f. alata, $4=$ M. rasilis, $5=$ M. maculata, $6=$ Synura echinulata, $7=$ Mallomonas tonsurata, $8=$ Synura lapponica, 9-10 = Spiniferomonas serrata . Scale bars $=1 \mu \mathrm{m}$.

no. 13 turned out to possess the richest flora with 18 chrysophyte species. Micrographs of scales of selected species are shown in Fig. 2 and 3.

Our present findings are in agreement with the generally accepted autecology of the individual chrysophyte species. Apart from species with ecological indifference, we found species preferring cold water (e.g. Chrysosphaerella brevispina, Mallomonas alata f. alata, Synura lapponica and Synura echinulata; Siver 1991, 1995). As the $\mathrm{pH}$ of the sites was more or less neutral, we found species usually preferring both slightly acidic (Synura sphagnicola, S. echinulata,
M. heterospina, Chrysosphaerella longispina) and alkaline water ( $M$. cf. acaroides, M. alpina, M. tonsurata) (Siver 1995). The alkaliphilous species $M$. tonsurata was observed only in the locality with the highest measured $\mathrm{pH}$ (7.8).

The most common species found in our samples was Synura echinulata that was collected at 13 sites. Interestingly, Siver et al. (2005) observed its predominant occurrence in a human impacted region of the Bolshezemelskaya tundra (Russia). Moreover, M. heterospina and M. matvienkoae have even been suggested as bioindicators of polluted water bodies (Siver 1995). The Abisko National 

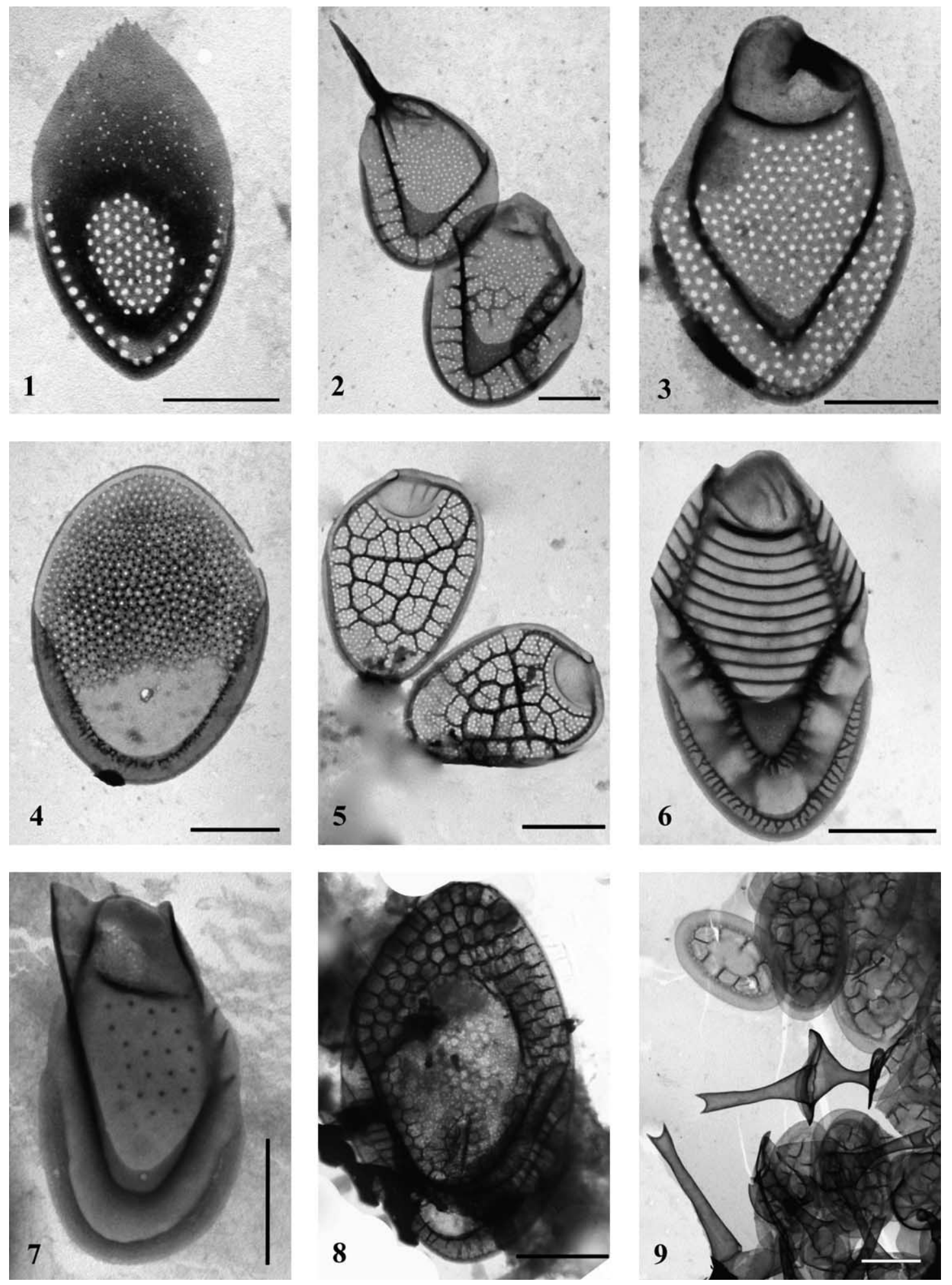

Figure 3. Silica scales of some chrysophyte species found in Abisko. $1=$ Mallomonas akrokomos, $2=$ M. crassisquama, weakly silicified body scale and spine bearing rear scale, $3=M$. alpina, $4=M$. matvienkoae var. matvienkoae, $5=M$. heterospina, $6=M$. striata, $7=$ M. papillosa var. papillosa, $8=$ M. insignis, $9=$ Chrysosphaerella longispina. Scale bars $=1 \mu \mathrm{m}$.

Park and its surroundings are popular tourist destinations in Sweden and the majority of the investigated sites lay near a main road, or at least a footpath. Consequently, a certain amount of human impact is doubtless present.
Regrettably, we did not succeed in discovering Synura obesa, even though this species was described quite recently from this same region (Němcová et al. 2008) and we sampled several, diverse localities. 
In some samples, we identified scales characteristic of the species Mallomonas acaroides. Nevertheless, we have decided to present them as Mallomonas cf. acaroides, due to the possibility that they are instead weakly silicified scales of $M$. crassisquama (Kristiansen 2002). However, the typical $M$. crassisquama scales (including the spine-bearing rear scales) were also found. At site number 13, both distinct types of scales were observed.

Some of the species we found have not been reported from Sweden before: Mallomonas maculata, M. rasilis and Spiniferomonas serrata.

\section{Mallomonas maculata (Fig. 2.5)}

This Mallomonas species is quite rare - its distribution is scattered (Kristiansen and Preisig 2007) and its autecology not known. However, it has previously been reported from northern regions. The species was described in 1964 from Iceland (Bradley 1964) and Siver et al. (2005) reported it from the Russian Arctic. We found a single scale in sampling site 16 , in water with a pH of 6.4 and conductivity of $78 \mu \mathrm{Scm}^{-1}$.

\section{Mallomonas rasilis (Fig. 2.4)}

This species is widely distributed (Kristiansen and Preisig 2007), but it has never previously been reported from such a high latitude region. Its autecology is unknown. We found two scales at site $13(\mathrm{pH} 6.5$, conductivity 77 $\mu \mathrm{Scm}^{-1}$ ).

\section{Mallomonas sp. (Fig. 2.1)}

These unknown scales resemble the scales of $M$. hexagonis more than any other Mallomonas species described thus far. Mallomonas hexagonis was described by Nicholls (1988), but the published scales' description lacked the U-shaped window on the shield observed in our samples. Siver et al. (2005) reported similar scales as 'Mallomonas sp. 1' from Bolshezemelskaya tundra (Russia). We found a rich population at site $13\left(\mathrm{pH} 6.5\right.$, conductivity $\left.77 \mu \mathrm{Scm}^{-1}\right)$.

\section{Spiniferomonas serrata (Fig. 2.9, 2.10)}

This member of the class Chrysophyceae was first described from Ontario, Canada (Nicholls 1979). Two types of scales were described, large oval and small elliptical with two lacunae. The base of its 9-15 $\mu \mathrm{m}$ long spines has a toothed margin (Nicholls 1979). It has also been reported from Greenland (Jacobsen 1985), Finland (Hällfors and Hällfors 1988) and the Russian Arctic (Siver et al. 2005). We observed $S$. serrata in 3 sites with a $\mathrm{pH}$ of 6.5 and the conductivity ranging between 31 and $73 \mu \mathrm{Scm}^{-1}$.

In conclusion, this study extends our knowledge of Arctic chrysophytes and improves our understanding of their geographical distribution. We believe that this further supports the hypothesis that there is no distinctive Arctic flora (Kristiansen 2001, Siver et al. 2005). We found primarily species with a cosmopolitan or worldwide distribution. However, we also found species whose occurrence is restricted to the Northern Hemisphere: Chrysosphaerella longispina and Synura lapponica (Kristiansen 2001); Mallomonas sp. may also belong to this group.

Acknowledgements - This study was supported by the Czech Ministry of Education, research grant no. 0021620828 and grant no. 206/08/P281 from the Czech Science Foundation. We would also like to thank Ladislav Hodač for his assistance during our field work, as well as the staff of the Scientific Research Station in Abisko for their kind support. We also thank Dr Jörgen Kristiansen for his comments and recommendations that led to improvements of the manuscript.

\section{References}

Bradley, D. E. 1964. A study of the Mallomonas, Synura and Chrysosphaerella of northern Iceland. - J. Gen. Microbiol. 37: 321-333.

Finlay, B. J. and Clarke, K. J. 1999. Apparent global ubiquity of species in the protist genus Paraphysomonas. - Protist 150: 419-430.

Hällfors, G. and Hällfors, S. 1988. Records of chrysophytes with siliceous scales (Mallomonadaceae and Paraphysomonadaceae) from Finnish inland waters. - In: Jones, R. I. and Ilmavirta, V. (eds), Flagellates in freshwater ecosystems. - Hydrobiologia 161: 1-29.

Jacobsen, B. A. 1985. Scale-bearing chrysophyceae (Mallomonadaceae and Paraphysomonadaceae) from west Greenland. - Nord. J. Bot. 5: 381-398.

Janatková, K. and Němcová, Y. 2009. Silica-scaled chrysophytes of southern Bohemian water bodies, including Mallomonas conspersa Dürrschmidt with occurrence so far reported from Japan and New Zealand. - Fottea 9: 93-99.

Kristiansen, J. 2001. Biogeography of silica-scaled chrysophytes. - Nova Hedw. Beih. 122: 23-39.

Kristiansen, J. 2002. The genus Mallomonas (Synurophyceae) - a taxonomic survey based on the ultrastructure of silica scales and bristles. - Opera Bot. 139: 5-128.

Kristiansen, J. 2008. Dispersal and biogeography of silica-scaled chrysophytes. - Biodivers. Conserv. 17: 419-426.

Kristiansen, J. and Lind, J. F. 2005. Endemicity in silica-scaled chrysophytes. - Nova Hedw. Beih. 128: 65-83.

Kristiansen, J. and Preisig, H. R. 2007. Chrysophyte and haptophyte algae. Part 2: Synurophyceae - In: Büdel, B. et al. (eds), Süsswasserflora von Mitteleuropa 2/2. Springer Verlag, pp. 1-252.

Němcová, Y. and Pichrtová, M. 2009. The rare species Synura lapponica (Synurophyceae) new to the Czech Republic, local vs global diversity in colonial synurophytes. - Biologia 64: 1070 1075.

Němcová, Y. et al. 2008. Synura obesa sp. nov. (Synurophyceae) and other silica-scaled chrysophytes from Abisko (Swedish Lapland). - Nova Hedw. 86: 243-254.

Nicholls, K. H. 1979. Spiniferomonas (Chrysophyceae) in Ontario lakes including a revision and descriptions of two new species. - Can. J. Bot. 59: 107-117.

Nicholls, K. H. 1988. Description of three new species of Mallomonas (Chrysophyceae): M. hexagonis, M. liturata and M. galeiformis. - Br. Phycol. J. 23: 159-166. 
Petersen, J. B. and Hansen, J. B. 1958. On the scales of some Synura species. II. - Biol. Meddel. Kungl. Danske Vidensk. Selsk. 23: 1-13.

Pichrtová, M. and Veselá, J. 2009. The silica-scaled chrysophytes of the Elbe sandstone region, Czech Republic. - Fottea 9: 101-106.

Rezáčová, M. and Neustupa, J. 2007. Distribution of the genus Mallomonas (Synurophyceae) - ubiquitous dispersal in microorganisms evaluated. - Protist 158: 29-37.
Siver, P. A. 1991 The biology of Mallomonas. Morphology, taxonomy, ecology. - Kluwer.

Siver, P. A. 1995. The distribution of chrysophytes along environmental gradients: their use as biological indicators. - In: Sandgren, C. D. et al. (eds), Chrysophyte algae. Cambridge Univ. Press, pp. 232-268.

Siver, P. A. et al. 2005. The scaled chrysophyte flora of the Bolshezemelskaya tundra (Russia). - Nova Hedw. Beih. 128: 125-150. 